\title{
High-Volume Fly Ash Concrete with and without Hydrated Lime: Chloride Diffusion Coefficient from Accelerated Test
}

\author{
J. Hoppe Filho'; M. H. F. Medeiros²; E. Pereira ${ }^{3}$; P. Helene, M.ASCE${ }^{4}$; and G. C. Isaia ${ }^{5}$
}

\begin{abstract}
Fly ash changes the microstructure of paste and can increase concrete durability. Calcium hydrated lime was added to concrete with $50 \%$ of the cement, by weight, substituted with fly ash, with the intent of replacing some of the calcium hydroxide consumed by the pozzolanic activity. Three proportions of mixes were studied: concrete with high early strength cement (HESC), concrete with 50\% HESC and 50\% fly ash, and concrete with 50\% HESC, 50\% fly ash and an additional 20\% of hydrated lime. They were then tested according to ASTM C1202, but with the application of a voltage of $30 \mathrm{~V}$ during $35 \mathrm{~h}$. Results revealed that concretes containing fly ash and hydrated lime presented a lower accumulated charge density and coefficient of chloride diffusion than the HESC concrete used as a reference. DOI: $\mathbf{1 0}$ .1061/(ASCE)MT.1943-5533.0000596. (C) 2013 American Society of Civil Engineers.
\end{abstract}

CE Database subject headings: Chloride; Fly ash; Concrete; Lime; Hydration.

Author keywords: Chloride diffusion; Migration; Fly ash; Hydrated lime; Concrete.

\section{Introduction}

The most serious causes of corrosion in reinforced concrete are localized depassivation of the steel due to chloride ion diffusion and complete depassivation due to acidification of water pores, resulting from reactions between hydrated compounds and carbon dioxide found in the atmosphere (Montemor et al. 2003). The permeation of chloride ions through concrete causes depassivation of the steel bars, reducing the service life of the structure. The diffusion process, the external chloride concentration, and the microstructure of the concrete determine how long it takes for the chloride ions to reach the steel (Andrade 1993).

The more fly ash is used in the production of concrete and cements, the more natural resources are preserved, such as clay, lime, and gypsum. Mineral coal ash, which is often dumped freely into the environment, causing pollution, is sometimes put to good use in the production of concrete and cements. The use of fly ash in concrete has many advantages because it refines the pores and increases the capillary tortuosity of the microstructure of the paste

\footnotetext{
${ }^{1}$ Dept. of Civil Engineering, Federal Univ. of Bahia, Barreiras, Bahia, Brazil.

${ }^{2}$ Dept. of Civil Engineering, Federal Univ. of Paraná, Curitiba, Paraná, Brazil; and DCC/UFPR, Centro Politécnico, Jardim das Américas, CEP: 81531-980, Curitiba, Paraná, Brazil (corresponding author). E-mail: medeiros.ufpr@gmail.com

${ }^{3}$ Dept. of Civil Engineering, Federal Univ. of Paraná, Curitiba, Paraná, Brazil.

${ }^{4}$ Dept. of Civil Construction Engineering, Univ. of São Paulo, São Paulo, Brazil.

${ }^{5}$ Structures and Civil Construction Dept., Federal Univ. of Santa Maria, Santa Maria, Rio Grande do Sul, Brazil.

Note. This manuscript was submitted on January 25, 2012; approved on May 25, 2012; published online on May 31, 2012. Discussion period open until August 1, 2013; separate discussions must be submitted for individual papers. This paper is part of the Journal of Materials in Civil Engineering, Vol. 25, No. 3, March 1, 2013. (C) ASCE, ISSN 0899-1561/2013/3-411$418 / \$ 25.00$.
}

(Sujjavanich et al. 2005; Chindaprasirt et al. 2007). Normally, those changes increase the service life of the concrete.

The partial substitution of cement with fly ash is efficient in reducing the migration and diffusion of chloride ions in concrete (Thomas 1996). This occurs due to the formation of secondary hydrated compounds that substitute portlandite with silicate and aluminate hydrates. The presence of fly ash also changes the distribution of cement particles in the paste, producing an increase in the capillary network tortuosity and decreasing the average pore size (Cyr et al. 2005; Hanehara et al. 2001).

The addition of hydrated lime partially replaces the portlandite that is either consumed by the fly ash or not produced, due to the smaller quantity of cement.

This work aims to measure the influence of fly ash and hydrated lime in concrete using the chloride ion migration test, chloride diffusion coefficient, porosity, pore size distribution, and X-ray diffraction.

\section{Experimental Procedure}

\section{Theoretical Considerations}

The flow of chloride ions through concrete is very complex due to the variety of ions found in the pore solution that have a direct effect on the electrical current. The dissolution of alkaline metals and calcium is responsible for the high $\mathrm{pH}$ of the water in the pores and has a significant influence on the conductivity. The extent of how much those ions affect the conductivity is currently unknown and can be disregarded if the solutions applied to the porous structure of the concrete (normally sodium hydroxide and sodium chloride) have enough conductivity to minimize the effects of the present ions (Mokhtar et al. 2007).

In test conditions according to ASTM C1202 (2005), the anions are mostly represented by hydroxyl and chloride ions. Hydroxyl is the primary ion responsible for the intensity of the electrical current because it has higher ionic conductivity $\left(198.0 \mathrm{~cm}^{2} / \Omega \cdot \mathrm{mol}\right)$ than 
the chloride ion $\left(76.3 \mathrm{~cm}^{2} / \Omega \cdot \mathrm{mol}\right)$ (Andrade 1993; Shi 2004; Snyder et al. 2003).

The pozzolanic activity of fly ash consumes the calcium hydroxide of the concrete; in consequence, the amount of hydroxyl in solution is reduced. In concretes containing $30 \%$ of fly ash, the concentration of hydroxyl in the pore solution can be less than $70 \%$ of the concentration observed in a similar concrete without fly ash (Thomas 1996). Therefore, in all probability, concrete containing fly ash has less electrical conductivity than concrete produced exclusively with portland cement.

The migration test measures the total electrical current corresponding to the entire ion movement in electrolytes. Only one part of the electrical current is attributable to the chloride ion and it is possible to estimate it by using the chloride transference number (Andrade 1993). To do this, the experimental procedure must be known, because the chloride transference number is a function of the ionic mobility and the equivalent conductivity of the solution. The transference number of one ion moving under the action of an external electrical field is defined by the proportion of electrical current conducted by this ion in relation to the total current conducted by all the ions. The transference number is formulated as follows [Eq. (1)] (Andrade 1993):

$$
t_{j}=\frac{i_{j}}{i}=\frac{z_{j} \cdot F \cdot \mu_{j} \cdot C_{j}}{\sum z \cdot F \cdot \mu \cdot C}=\frac{\lambda_{j}}{\Lambda}
$$

where $t_{j}=$ transference number; $i_{j}=$ amount of electric current of ion $j(\mathrm{~mA}) ; i=$ total electric current $(\mathrm{mA}) ; z_{j}=$ ion valence of ion $j ; F=$ Faraday constant $(96,485.3383 \mathrm{~J} / \mathrm{V} \cdot \mathrm{mol}) ; \mu_{j}=$ ionic mobility of ion $j\left(\mathrm{~cm}^{2} / \Omega \cdot \mathrm{mol}\right) ; C_{j}=$ molar concentration of ion $j$; $\lambda_{j}=$ molar ionic conductivity of ion $j\left(\mathrm{~cm}^{2} / \Omega \cdot \mathrm{mol}\right) ; \Lambda=$ solution equivalent conductivity $\left(\mathrm{cm}^{2} / \Omega \cdot \mathrm{mol}\right)$.

Because this equation only involves the conditions of the solutions used in the test and not the solubility of the ions of the concrete, part of the electrical current due to the chloride is maximized, and therefore, the estimate is not entirely accurate.

Another important factor in a migration test is to estimate the chloride diffusion coefficient. The testing method used in this work for estimating the chloride diffusion coefficient is in accordance

Table 1. Physical Properties of Materials

\begin{tabular}{lcc}
\hline Material & $\begin{array}{r}\text { Specific gravity } \\
\left(\mathrm{g} / \mathrm{dm}^{3}\right)\end{array}$ & $\begin{array}{c}\text { Blaine specific surface } \\
\text { area }\left(\mathrm{m}^{2} / \mathrm{kg}\right)\end{array}$ \\
\hline Cement (HESC) & 3.02 & 514 \\
Fly ash & 2.38 & 678 \\
Hydrated lime & 2.26 & 1597 \\
\hline
\end{tabular}

Table 2. Chemical Composition of Materials

\begin{tabular}{lcrrrrrr}
\hline Materials & $\mathrm{SiO}_{2}$ & $\mathrm{Al}_{2} \mathrm{O}_{3}$ & $\mathrm{Fe}_{2} \mathrm{O}_{3}$ & $\mathrm{CaO}$ & $\mathrm{MgO}$ & $\mathrm{SO}_{3}$ & $\begin{array}{c}\text { Loss of } \\
\text { ignition }\end{array}$ \\
\hline Cement (HESC) & $17.1 \%$ & $3.7 \%$ & $3.1 \%$ & $64.8 \%$ & $0.7 \%$ & $4.6 \%$ & $4.1 \%$ \\
Fly ash & $63.6 \%$ & $25.1 \%$ & $2.7 \%$ & $4.0 \%$ & $1.0 \%$ & $0.3 \%$ & $2.0 \%$ \\
\hline
\end{tabular}

with the procedure described by Luping and Nilsson (1992) and Geiker et al. (1995). The colorimetric method is based on the measurement of the depth of color change in the surface of the concrete, freshly broken in two halves in the direction of the flow of chloride ions, spraying an aqueous solution of silver nitrate $\left(0.1 \mathrm{M} \mathrm{AgNO}_{3}\right)$, and subsequently, based on the application of Eq. (2):

$$
D=\frac{R \cdot T}{z \cdot F \cdot E} \cdot \frac{x_{d}-a \cdot x_{d}^{b}}{t}
$$

where $D=$ chloride diffusion coefficient $\left(\mathrm{m}^{2} / \mathrm{s}\right) ; R=$ gas constant $(8.314472 \mathrm{~J} / \mathrm{mol} \cdot \mathrm{K}) ; T=$ temperature $(298 \mathrm{~K}) ; z=$ ion valence $\left(\mathrm{Cl}^{-}=-1\right) ; F=$ Faraday constant $(96,485.3383 \mathrm{~J} / \mathrm{V} \cdot \mathrm{mol}) ; E=$ electric field $(-600 \mathrm{~V} / \mathrm{m}) ; x_{d}=$ penetration depth $(\mathrm{m}) ; t=$ testing time (s); $a=$ constant to $E=-600 \mathrm{~V} / \mathrm{m}(0.0622) ; b=$ constant to $E=-600 \mathrm{~V} / \mathrm{m}(0.589)$.

The model is based on Fick's second law because the test takes place in a non-steady-state condition.

At the end of the test, when the aqueous silver nitrate solution is sprayed on the surface of the concrete containing chloride ions, a chemical reaction takes place. The chloride ions bind with the silver to form silver chloride $(\mathrm{AgCl})$, a white chemical substance. In the absence of chloride ions, the silver binds with the hydroxides present in the concrete, resulting in a brownish color (Mokhtar et al. 2007).

This method has been successfully applied in other works (Medeiros and Helene 2009; Medeiros et al. 2009).

\section{Materials}

High early strength cement (HESC), in accordance with Brazilian standard ABNT NBR 5733 (Associação Brasilieira de Normas Tecnicas 1991), low-calcium fly ash, and calcium hydrated lime were used. The specific gravity measured by helium picnometry and the Blaine specific surface area of each material are shown in Table 1.

The chemical composition of cement and fly ash was determined by X-ray fluorescence (Table 2).

The hydrated lime had $60 \%$ calcium hydroxide and $32 \%$ calcium carbonate, measured by thermogravimetry using the equipment NETZSCH STA 409 PG.

The fly ash glass phase, determined by Rietveld X-ray diffraction with lithium fluorite (griceite) as internal standard, was $57.7 \%$, with $42.3 \%$ crystalline compound in quartz, mullite, and hematite forms.

The coarse aggregate consisted of crushed and washed granite using the fraction between 19.0 and $6.3 \mathrm{~mm}$. Quartz sand, washed and sieved through a $4.8-\mathrm{mm}$ mesh, was used as fine aggregate.

In this study, a water-reducing admixture with chemical base was used on modified polycarboxylic ether.

\section{Concrete Mix Proportions}

The concrete mix proportions are shown in Table 3. Different ratios of water and cementitious materials were considered for the

\begin{tabular}{|c|c|c|c|c|c|c|c|c|}
\hline Legend & $\begin{array}{c}\mathrm{w} / \mathrm{cm}^{\mathrm{a}} \\
(\mathrm{kg} / \mathrm{kg})\end{array}$ & $\begin{array}{c}\text { Portland } \\
\text { cement } \\
\left(\mathrm{kg} / \mathrm{m}^{3}\right)\end{array}$ & $\begin{array}{l}\text { Fly ash } \\
\left(\mathrm{kg} / \mathrm{m}^{3}\right)\end{array}$ & $\begin{array}{c}\text { Hydrated } \\
\text { lime } \\
\left(\mathrm{kg} / \mathrm{m}^{3}\right)\end{array}$ & $\begin{array}{c}\text { Fine } \\
\text { aggregate } \\
\left(\mathrm{kg} / \mathrm{m}^{3}\right)\end{array}$ & $\begin{array}{c}\text { Coarse } \\
\text { aggregate } \\
\left(\mathrm{kg} / \mathrm{m}^{3}\right)\end{array}$ & $\begin{array}{l}\text { Water } \\
\left(\mathrm{L} / \mathrm{m}^{3}\right)\end{array}$ & $\begin{array}{c}\text { Admixture } \\
\left(\mathrm{kg} / \mathrm{m}^{3}\right)\end{array}$ \\
\hline HESC & 0.52 & 304 & - & - & 872 & 1,088 & 157.9 & 0.60 \\
\hline HESC + fly ash & 0.42 & 189 & 189 & - & 758 & 1,088 & 158.2 & 1.05 \\
\hline HESC + fly ash + hydrated lime & 0.43 & 179 & 179 & 72 & 743 & 1,054 & 152.2 & 2.25 \\
\hline
\end{tabular}

Table 3. Proportions of Concrete Mix

${ }^{\mathrm{a}} \mathrm{cm}$ : cementitious materials; portland cement + fly ash. Slump: $85 \pm 10 \mathrm{~mm}$. 
concretes to have the exact compressive strength of $55 \mathrm{MPa}$ at 91 days. Cementitious materials $(\mathrm{cm})$ are equivalent to the portland cement added to fly ash.

Fifty percent of the cement mass was replaced by low-calcium fly ash. To supply the portlandite consumed by the pozzolanic activity, 20\% hydrated lime (in mass) was added to the content of the cementitious materials.

The cylindrical specimens (10 cm diameter and $20 \mathrm{~cm}$ length) were cured in a wet chamber at $23 \pm 2{ }^{\circ} \mathrm{C}$ and $95 \%$ relative humidity for 91 days for the compressive strength test and for exposure to a particular chloride test.

\section{Chloride Migration Test}

After 91 days in the wet chamber, 50-mm-thick slices were obtained by sawing two slices from the middle portion of the cylindrical specimens $(\phi 10 \times 20 \mathrm{~cm})$, which were stored in a laboratory environment until the test. The lateral surfaces of the slices were sealed with silicon sealant. The slices were then placed in a desiccator chamber with both of their circular sides exposed in the confined environment, and $1 \mathrm{~mm} \mathrm{Hg}$ vacuum was applied for three hours. After that, deaerated water (distilled water boiled for $30 \mathrm{~min}$ ) was added to the desiccator chamber to cover all the specimens under vacuum for one more hour. The vacuum pump was turned off and air was allowed into the desiccator chamber, and the specimens were kept under water for $18 \pm 2 \mathrm{~h}$.

This test was conducted according to ASTM C1202 (2005) recommendations; however, the power source applied was $30 \mathrm{~V}$ for $35 \mathrm{~h}$. The reduction from 60 to $30 \mathrm{~V}$ was intended to reduce any interference in ionic conductivity due to the heat generated by the electric current passing through the electrolyte (Joule effect). The increase in test time, from 6 to $35 \mathrm{~h}$, allowed a significant migration of ions to the inner concrete, which allowed the determination of the depth reached by those ions in different mix proportions. The schematic representation of the migration cell is shown in Fig. 1.

\section{Colorimetric Test}

After the electrical field was switched off, the specimens were split in two halves and the penetration of chlorides was measured by spraying a silver nitrate aqueous solution $\left(0.1 \mathrm{M} \mathrm{AgNO}_{3}\right)$ on the freshly broken concrete surfaces.

\section{Mercury Intrusion Porosimetry}

Pore size distribution was determined in samples of mortar extracted from the 91-day-old concretes. The mortar was separated

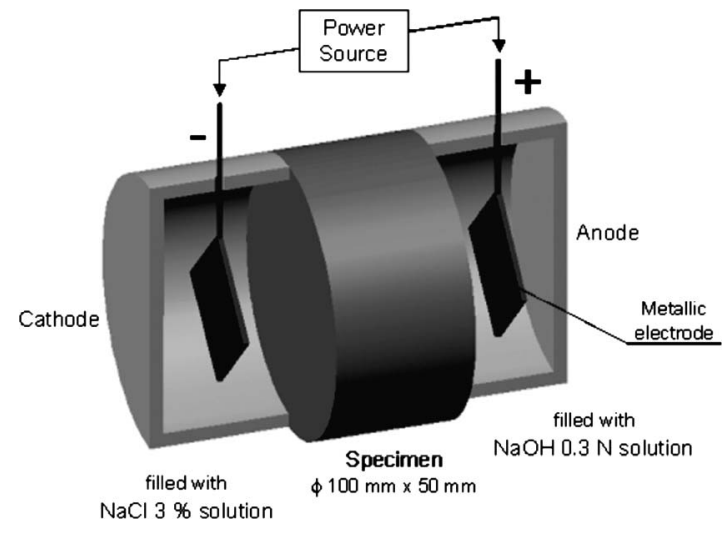

Fig. 1. Schematic representation of the migration cell from the coarse aggregate using a hammer and cut into thin slices sawn from the concrete cylindrical sample. Before this test, the hydration of the mortars was interrupted by liquid nitrogen freezing, followed by lyophilization (freeze-drying) to remove the free, adsorbed, and parts of the interlamellar water. The equipment was a Micromeritics porosimeter model Autopore III 9420, able to apply a maximum pressure of mercury intrusion of $414 \mathrm{MPa}$.

\section{X-Ray Diffraction}

After the chloride ion migration test, the specimens were cut using a diamond saw in 5-mm slices from each circular side of the concrete slices. The mortar was extracted from those samples. This produced two mortar samples for each specimen: one sample was submitted to an $\mathrm{NaOH} 0.3 \mathrm{~N}$ solution and the other to an $\mathrm{NaCl}$ $3 \%$ solution. They were then frozen in liquid nitrogen and lyophilized. For the X-ray diffraction test, each sample was ground until the mortar particles were smaller than $75 \mu \mathrm{m}$ to prevent any of the fine aggregate from being retained in the $75-\mu \mathrm{m}$ sieve.

The ground and sieved mortar samples were manually pressed in a 27-mm diameter sample holder and tested using PANalytical X'Pert MPD equipment with an X'Celerator detector. The measurements were made between 7 and $20^{\circ} 2 \theta$ with an angular step of $0.02^{\circ} 2 \theta$ and a 40 -s time step. A tube with copper anode LLF, $40 \mathrm{kV} / 40 \mathrm{~mA}$, with $1^{\circ}$ divergent crack, was used for the analyses. The sample spin was $60 \mathrm{rpm}$.

\section{Test Results and Discussion}

\section{Compressive Strength}

Fig. 2 shows the results of compressive strength at 91 days of age. From this age, the compressive strengths of the concretes were very similar to each other, allowing the comparison of ion chloride migration restrictions of the concretes in the same compressive strength.

To maintain the same compressive strength at 91 days old, the ratio of water/cementitious materials was decreased in concretes with pozzolan, resulting in an increase in the consumption of binding materials (portland cement + fly ash). In concrete with fly ash, the increase was $24 \%$ in mass. When hydrated lime was added, the consumption (portland cement + fly ash) increased by $18 \%$. Although there was an increase in the consumption of cementitious materials, there was also a decrease of $38 \%$ in portland cement in concrete containing fly ash and a decrease of $41 \%$ in concrete containing fly ash and hydrated lime.

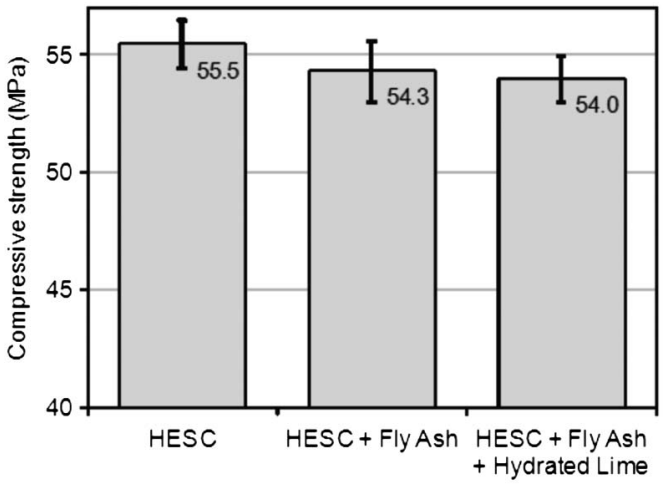

Fig. 2. Compressive strength of concretes at 91 days 


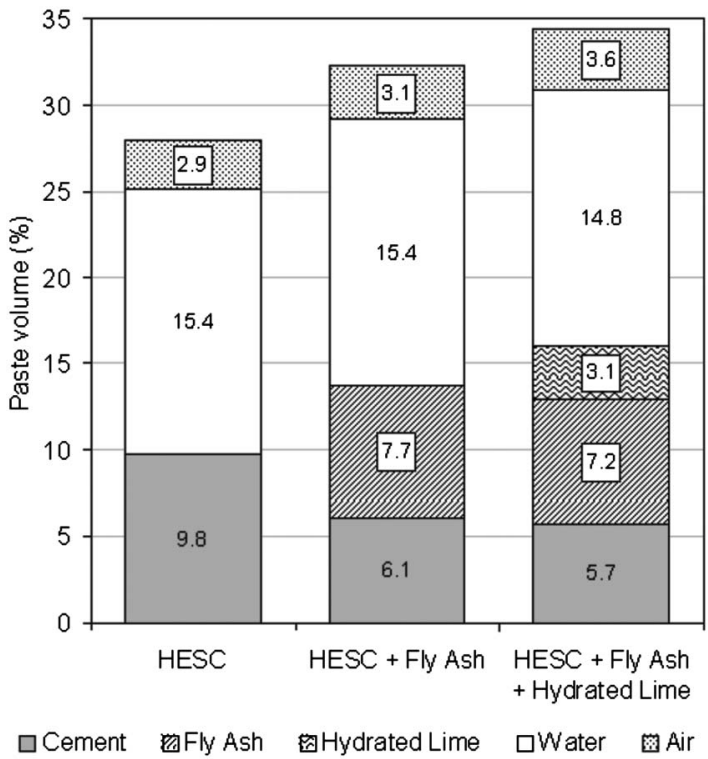

Fig. 3. Percentage of paste volume in the concretes

\section{Migration of Chloride lons}

The use of different amounts of cementitious materials resulted in different quantities of paste in the concretes. It is necessary to know the composition of the paste to analyze the migration of chloride ions. The three concrete pastes, in volumetric percentages, are shown in Fig. 3. The volumetric percentage for each material was obtained by dividing the weight consumption by the respective density, considering the increasing in total volume due to air entrained in the concrete.

The volume occupied by water and entrained air in all concretes is very similar. However, when $50 \%$ of the portland cement was substituted in mass with fly ash, the volume of cementitious material increased by $40 \%$ due to the lower density of fly ash. The same behavior was observed in concrete with an addition of hydrated lime, resulting in an increase of $62 \%$.

Chloride ions migrate through the volume occupied by hydrated paste, free water, and entrained air. The use of fly ash increased the final volume of paste by $15 \%$, and the addition of hydrated lime increased the volume by $22 \%$. In this way, the volumetric analysis of paste shows that the utilization of fly ash and hydrated lime makes the concretes more susceptible to the migration of chloride ions, something that does not occur under reliable conditions. The fly ash modifies the pore structure of the hydrate matrix, increasing the capillary network tortuosity and decreasing pore interconnectivity due to the C-S-H formation by pozzolanic activity (Li and Roy 1986). The reduction of the amount of Interface Transition Zone on concrete is also perceived, which tends to reduce the susceptibility for the migration of chloride ions.

Fig. 4 shows the charge density, in coulombs, that migrated through the concretes in the first $12 \mathrm{~h}$ of testing. Because the applied power source was $30 \mathrm{~V}$, the 12 -h period corresponds to the ASTM C1202 standard (2005), which recommends testing at $60 \mathrm{~V}$ for $6 \mathrm{~h}$. The classification of the reference concrete (HESC) falls between low and moderate penetrations, whereas the concretes using fly ash, with or without hydrated lime, are classified as having a very low penetration of chloride ions.

These results refer to all of the ions present in the electrolyte, but without distinguishing the contribution of the ion chloride in the density of the charge passed through the concrete. To determine the contribution of ions in the total ionic mobility of the electrolyte,

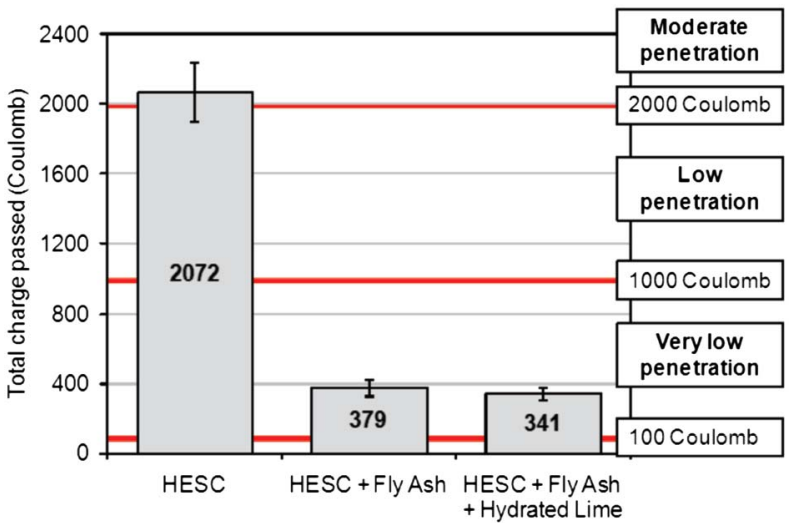

Fig. 4. Charge density passed in concretes after 12-h exposition in $30-\mathrm{V}$ electrical field

Table 4. Equivalent Conductivity at Infinite Dilution $\lambda^{\circ}$ (Andrade 1993; Shi 2004; Snyder et al. 2003)

\begin{tabular}{lc}
\hline Species & $z \lambda^{o}\left(\mathrm{~cm}^{2} \cdot \mathrm{S} / \mathrm{mol}\right)$ \\
\hline $\mathrm{OH}^{-}$ & 198.0 \\
$\mathrm{Na}^{+}$ & 50.1 \\
$\mathrm{Cl}^{-}$ & 76.4 \\
$\mathrm{Ca}^{+2}$ & 59.5 \\
\hline
\end{tabular}

the transference number of the hydroxyl ions, chloride, and sodium should be ascertained. This was conducted by using the equivalent value of conductivity, considering an infinite solution of the primary ion involved in the migration test. The values are shown in Table 4, in accordance with relevant literature (Andrade 1993; Shi 2004; Snyder et al. 2003).

Because the solutions used in the migration test were $\mathrm{NaCl} 3 \%$ and $\mathrm{NaOH} 0.4 \mathrm{~N}$, molar concentrations were $\mathrm{NaCl} 0.5 \mathrm{M}$ and $\mathrm{NaOH} 0.3 \mathrm{M}$, respectively. The transference numbers of ions are calculated using Eq. (1) as shown in the following example, resulting in 0.28 to chloride, 0.43 to hydroxyl, and 0.29 to sodium:

$$
\begin{aligned}
t_{\mathrm{Cl}^{-}} & =\frac{\lambda_{\mathrm{Cl}^{-}}}{\Lambda}=\frac{0.5 \times 76.4}{0.5 \times 50.1+0.5 \times 76.4+0.3 \times 50.1+0.3 \times 198.0} \\
& \rightarrow t_{\mathrm{Cl}^{-}}=0.28
\end{aligned}
$$

The chloride ion is responsible for $28 \%$ of the total charge density and the hydroxyl and sodium are responsible for $72 \%$.

The total charge density and the fraction related to the chloride ions in the concretes, after $35 \mathrm{~h}$ under a power source of $30 \mathrm{~V}$, are shown in Fig. 5. The reference concrete presented a charge

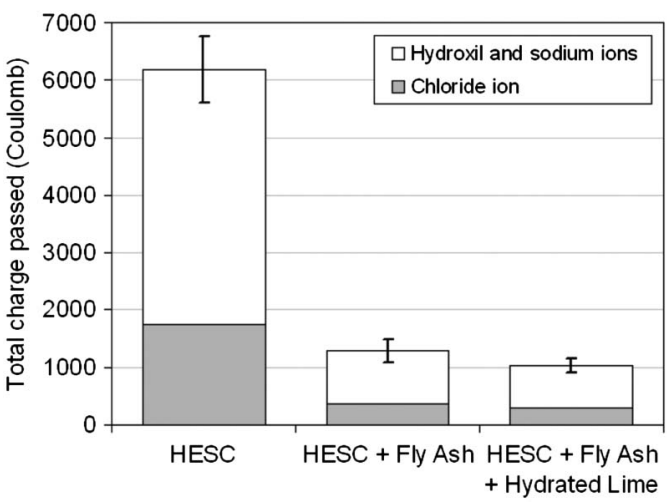

Fig. 5. Total charge passed in investigated concretes 
migration five times higher than the concretes containing fly ash, with or without hydrated lime.

At ages up to 180 days, pastes that had 30 to $60 \%$ of the cement substituted with fly ash, by mass, contained a lower amount of chemical binding water than hydrates (Massazza 1998; Zhang et al. 2000), making the migration of chloride ions difficult, primarily due to the physical barrier. This physical barrier is attributable to the more extensive tortuosity, the lower permeability of the pore capillary network, and the adsorption of the capillary surface (solvatation). The solvatation is related to the anodic and cathodic attractions that are produced by the hydrates and particles present in the paste.

\section{Chloride Diffusion Coefficient}

Fig. 6 presents a sample of concrete with fly ash and hydrated lime after the colorimetric test. In the reference concrete (HESC), the color change occurred at an average depth of $37.9 \mathrm{~mm}$. Concrete with fly ash presented an average depth of $7.2 \mathrm{~mm}$, and with the addition of hydrated lime, an average depth of $7.9 \mathrm{~mm}$.

The chloride diffusion coefficients (Fig. 7) were calculated by using the equation proposed by Luping and Nilsson (1992) [Eq. (2)] and the measured results of the colorimetric test. HESC concrete presented a chloride diffusion coefficient that was seven times higher than the concretes containing pozzolanic material, with or without hydrated lime.

According to Andrade et al. (1999), the charge density by area unit may be related to color change. The relations for all concrete samples tested in this work are shown in Fig. 8. The linear relationship $\left[\left(Q / \mathrm{cm}^{2}\right)=2.04 \mathrm{~mm}\right]$ was obtained between passed charge and depth at which color change takes place. This relationship is similar to that presented by Andrade et al. (1999).

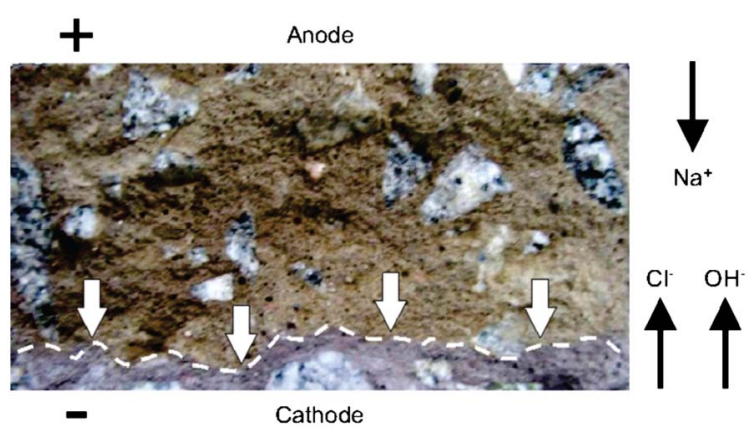

Fig. 6. Colorimetric test in concrete with fly ash and hydrated lime

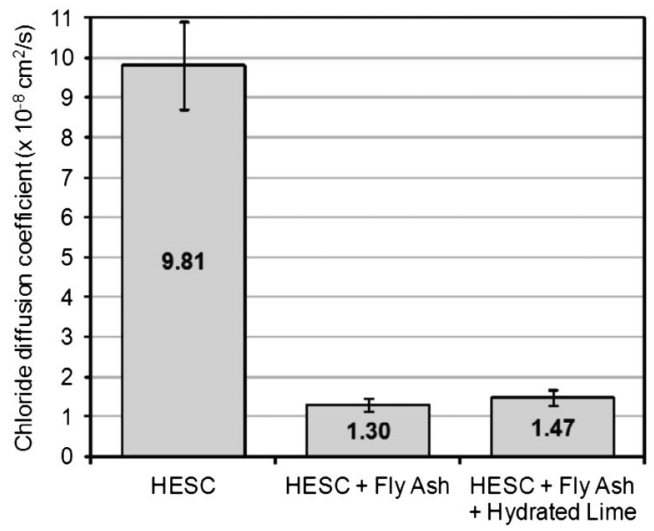

Fig. 7. Chloride diffusion coefficient of concretes

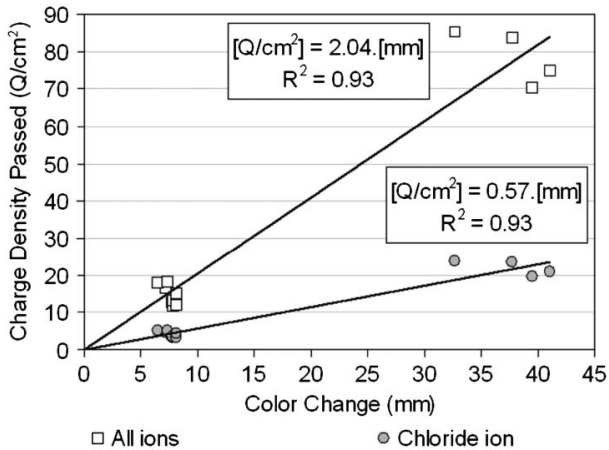

Fig. 8. Passed charge density versus depth at which the color change takes place

\section{Electrical Resistivity of Concrete}

The electrical resistance of concrete to the electrolytic solution is the relation between the applied power source and the intensity of the electric current; therefore, the electrolyte of the concrete follows Ohm's law.

The average electric current measured during $35 \mathrm{~h}$ of testing was used to determine the electrical resistance of the concretes. The electrical resistivity in saturated state was determined using Eq. (3). The resistor length $(5 \mathrm{~cm})$ is represented by the thickness of the specimen and the transversal section area $\left(78.5 \mathrm{~cm}^{2}\right)$ was obtained from the diameter of the sample.

$$
\rho=\frac{R \cdot S}{L}
$$

where $\rho=$ electrical resistivity of resistor (ohm.cm); $R=$ electrical resistance of circuit (ohm); $S=$ area of transversal section of resistor $\left(\mathrm{cm}^{2}\right) ; L=$ resistor length $(\mathrm{cm})$.

However, there is an error associated with this result because the loss of power occurs in the interface of electrodes and electrolyte due to the reactions of the electrolysis of the water and the loss of anode oxidation.

For a power source of $30 \mathrm{~V}$, the previously mentioned loss becomes negligible in relation to the high value $(\mathrm{K} \Omega \cdot \mathrm{cm})$ of the electrical resistivity of concrete. Fig. 9 presents the resistivity values of the concretes. The concretes containing fly ash with or without hydrated lime presented a higher resistivity than the reference one.

According to CEB 192 (Comité Euro-International du Béton 1989), the reinforced steel in the reference concrete with resistivity below $10 \mathrm{~K} \Omega \cdot \mathrm{cm}$ has a high probability of corroding, although the probability of this occurring in concrete with fly ash and hydrated

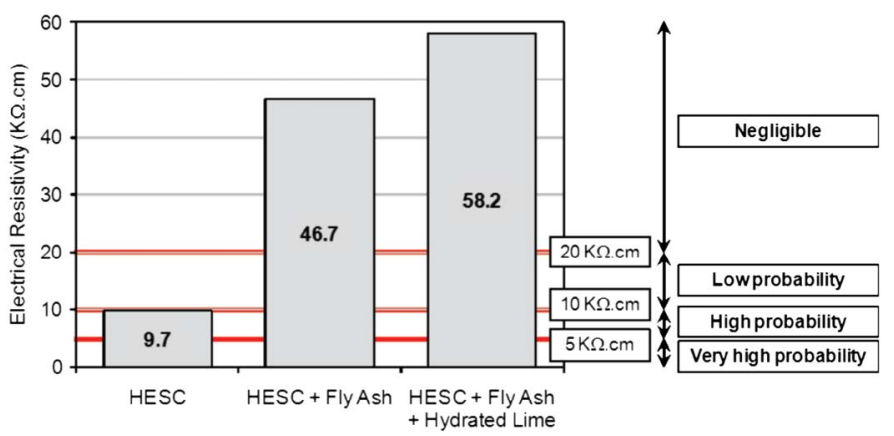

Fig. 9. Electrical resistivity of investigated concretes 
lime is negligible. Therefore, the resistivity of the concrete is related to the inhibition of the migration of chloride ions, which are subordinated to the flow paths in the microstructure of the paste. The formation of flow paths in the reference concrete results from the hydration of the cement. In concrete containing fly ash, the flow paths depend not only on the hydration of the cement, but also on the chemical effect of the pozzolanic activity (Li and Roy 1986). Beyond the pore structure, in blended cement, the ion concentration on the pore solution differs from ordinary portland cement, significantly reducing the migration of chloride ions across the hydrate matrix.

The long-term kinetic reaction of fly ash alters the original microstructure formed by the cement during the initial stages. Fly ash particles fill the pores and increase the tortuosity of the capillary network, resulting in longer paths and smaller pore diameters (Kobayawa et al. 2003). The reduction in pore diameter intensifies the interaction between the soluble ions, the particles, and the hydrates. In consequence, the ionic mobility in electrolytic solutions is decreased (Poon et al. 2000).

\section{Porosity and Pore Diameter Distribution}

Fig. 10 presents the porosity and the accumulated distribution of pore sizes in mortars extracted from the respective concretes. Concrete with HESC presented a porosity of $16.8 \%$ with cement and of $22.3 \%$ with fly ash. With the addition of hydrated lime, the porosity was $21.4 \%$. The use of fly ash in partial substitution of portland cement increases the porosity of mortars extracted from concrete because of the smaller amount of cement in mix proportions. The hydration of cement fills the volume initially occupied by the water, reducing the total porosity of the systems. The pozzolanic activity of fly ash consumes portlandite and precipitates secondary $\mathrm{C}-\mathrm{S}-\mathrm{H}$, without changing the porosity, but reducing the interconnectivity of the pore structure. However, the porosity of the hydrate matrix is controlled by the amount and hydration degree of portland cement, whereas fly ash only reduces the pore diameter.

The distribution of pore diameters in Fig. 11 shows that $49 \%$ of the pore sizes in the reference concrete are below $100 \mathrm{~nm}$, whereas in concrete with fly ash, they are $53 \%$, and with the addition of hydrated lime, they reach $65 \%$.

The utilization of fly ash, with or without the addition of hydrated lime, increased the total porosity of concrete but decreased the pore size (pores refinement), which is directly related to durability.

\section{X-Ray Diffraction}

The results in Fig. 12 show that the portlandite was consumed when fly ash was included in the concrete, and that the addition of hydrated lime increased the remaining calcium hydroxide.

Portlandite produced with hydrated cement is purer and more reactive than that found in commercial hydrated lime. Therefore, in concrete containing fly ash, there was an expressive consumption of portlandite, resulting from the hydration of $\mathrm{C}_{3} \mathrm{~S}$ and $\mathrm{C}_{2} \mathrm{~S}$, which left a very small amount of portlandite remaining. Presumably, the addition of hydrated lime increased the amount of portlandite in concrete produced with cement and fly ash, above the amount found in the reference concrete. However, pozzolanic reactions consumed a great portion of the total portlandite. Although the calcium hydroxide in hydrated lime was less reactive than that produced from hydrated cement, it had an accelerating effect on the pozzolanic activity, which resulted in lower amounts of portlandite than those found in the reference concrete after 91 days.
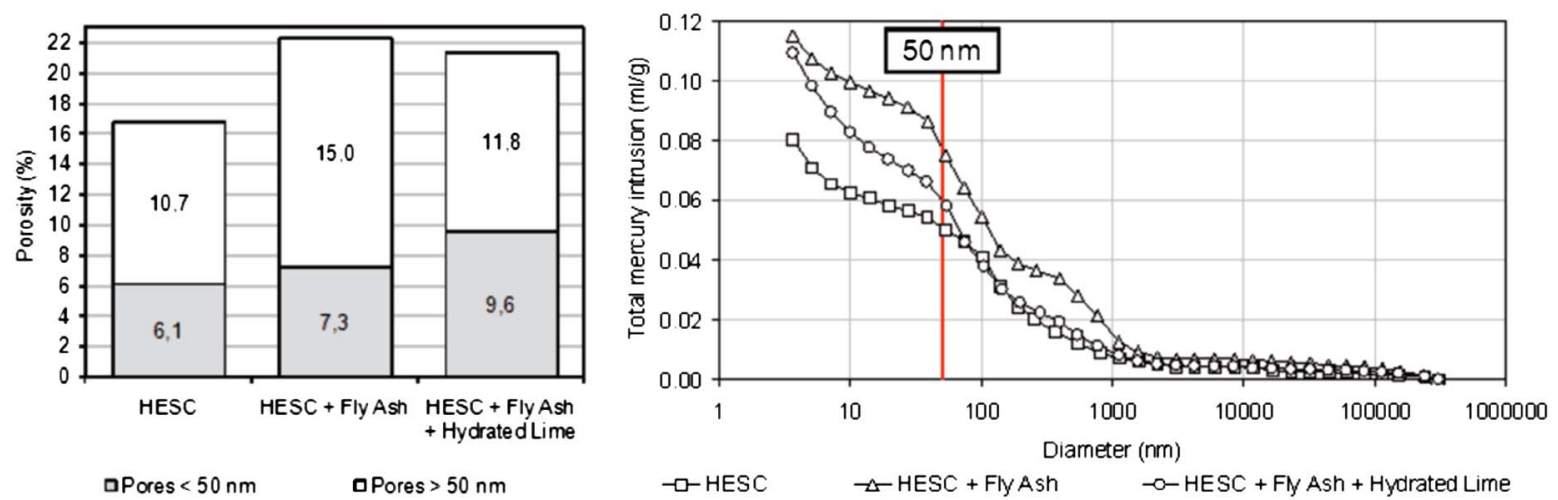

Fig. 10. Porosity and total mercury intrusion in concretes
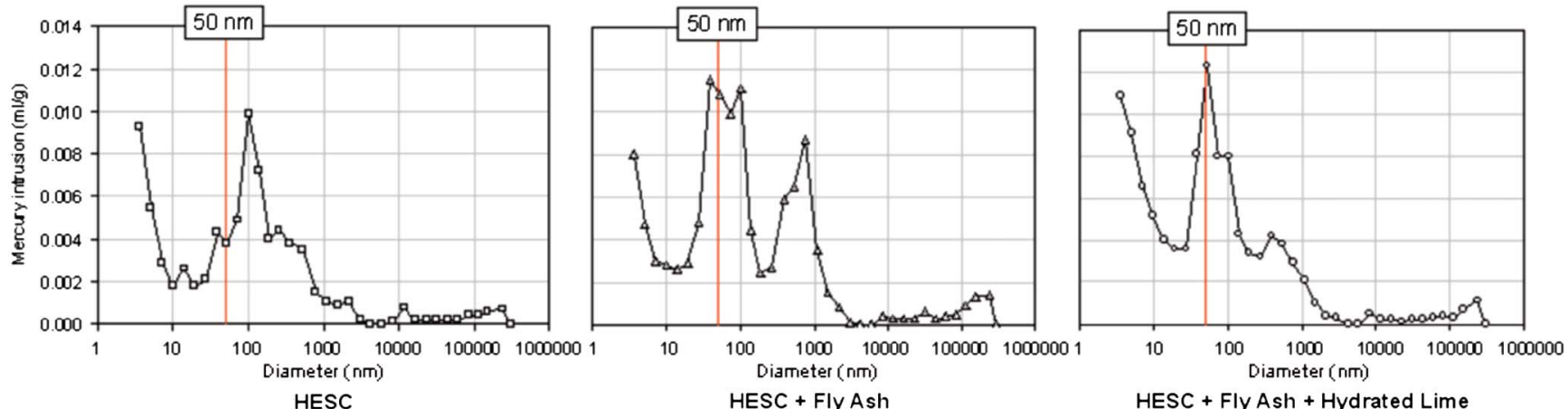

Fig. 11. Pore size distribution 


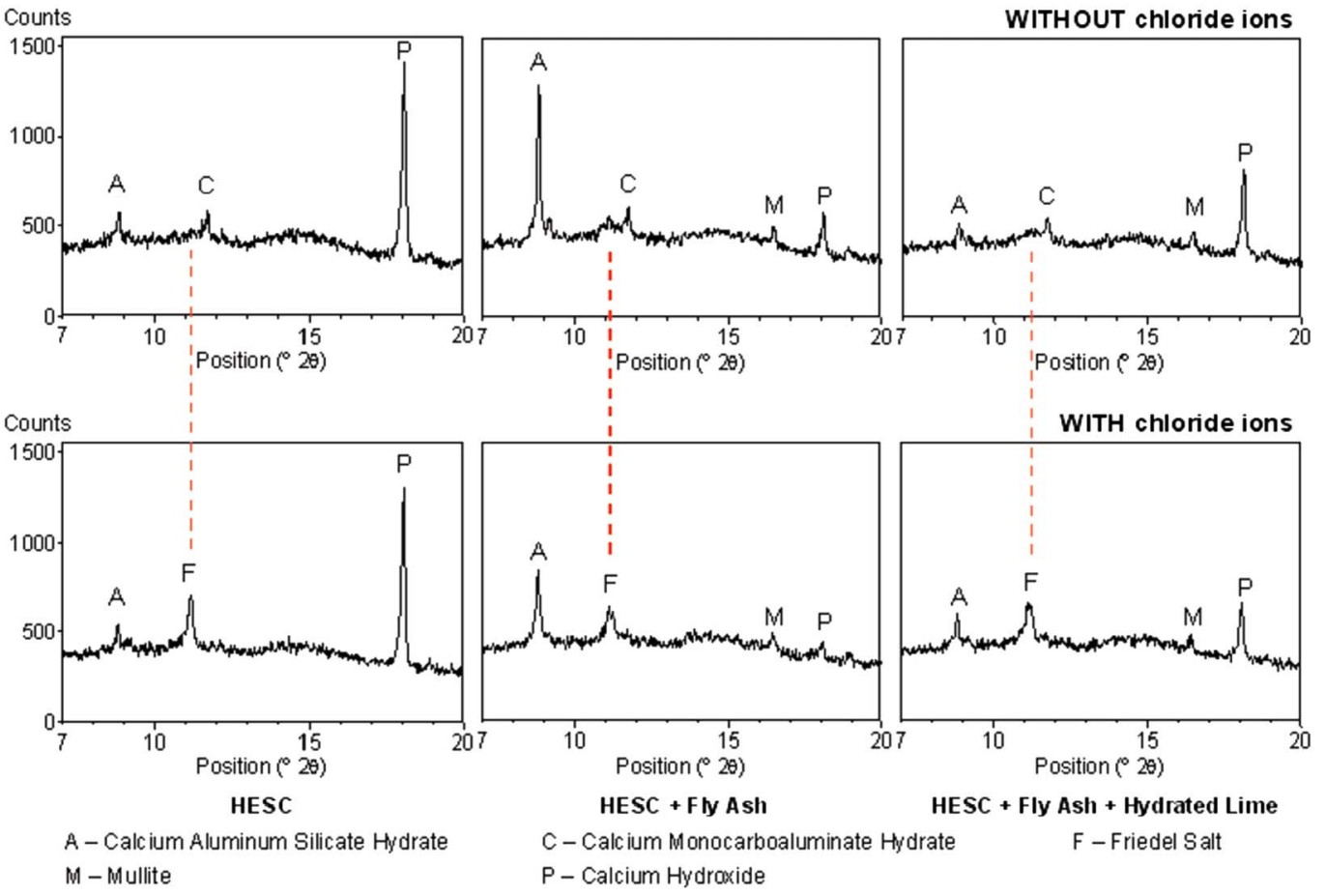

Fig. 12. X-ray diffraction of concretes after migration test in samples with and without chloride ions

In concretes with pozzolan, there was a peak that refers to mullite, one of the crystalline phases of fly ash. All concretes present a peak at an angle of $8.84^{\circ} 2 \theta$. This peak stood out in concrete with cement and fly ash. The peak is attributed to the formation of calcium aluminum silicate hydrate, which is identified as gismondine $\left(\mathrm{CaAl}_{2} \mathrm{Si}_{2} \mathrm{O}_{8} \cdot 4 \mathrm{H}_{2} \mathrm{O}\right)$ (20-0452 of International Centre for Diffraction Data). When hydrated lime was added, the formation of gismondine did not happen with the same intensity as in concrete with cement and fly ash.

Calcium monocarboaluminate hydrate was found in all samples not exposed to chloride ions. However, concrete exposed to chloride ions did not present this compound; in its place, Friedel salt was formed, indicating an exchange of divalent anion $\mathrm{CO}_{3}^{-2}$ for the chloride ion, as shown in Fig. 12.

The reference concrete also presented the formation of Friedel salt with an intensity count similar to that of concretes containing fly ash. Therefore, the higher restriction to the penetration of chloride ions in concretes containing fly ash cannot be attributed to the mechanism of chemical binding, whether by chemical adsorption or by anionic exchange. This is due to the physical interaction of the chloride ions with the hydrated paste, which are those immobilized by the electrostatic surface attraction of the hydrated microstructure.

\section{Conclusions}

The following considerations were determined in this work.

To maintain the same compressive strength of the reference concrete at 91 days, concretes containing $50 \%$ of fly ash must have reduced the ratio of water to cementitious materials (cement + fly ash). This results in an increase on the consumption of binding materials. However, because $50 \%$ of the mass was composed of fly ash, there was a reduction in the quantity of portland cement utilized.
The utilization of fly ash reduced the charge density, which migrated through the concrete. The addition of hydrated lime, however, had no effect on the result.

Colorimetric testing revealed that the use of fly ash and hydrated lime reduced the depth of the color change, indicating lower diffusion coefficients of chloride ions in relation to the reference concrete that was cast with HESC.

A good relation was observed between the depth of color change and the charge density passed by the area unit. This is corroborated by the work of Andrade et al. (1999).

The volume of paste in the concretes was not a determining factor on the migration of chloride ions. Improvements in the microstructure properties of the paste due to the presence of fly ash and hydrated lime were relevant in restricting the penetration of chloride ions.

The electrical resistivity was determined by monitoring the average electrical current during $35 \mathrm{~h}$ of testing and applying the Ohm's law. The result indicated that the use of fly ash increased the resistivity of concrete.

The porosity in concretes containing fly ash increased when compared with reference concrete. This, however, reduced the pore size, and changed the transport properties of chloride ions and reduced both the passed charge and the chloride ion diffusion coefficient.

X-ray diffraction showed that the fly ash decreased the amount of calcium hydroxide in relation to the reference concrete. The addition of hydrated lime to minimize this effect increased the remaining amount of portlandite, but the final result was still lower than the reference concrete (HESC).

The results of this paper imply that forecasts concerning the durability of concrete based on compressive strength are inappropriate, taking into account that concretes with the same compressive strength have distinct chloride diffusion coefficients, primarily when mineral admixtures are used. This is the opposite of the conclusions by Ramezanianpour and Malhotra (1995), 
Konin et al. (1998), Aldea et al. (2000), Wee et al. (2000), and Loser et al. (2010), who found a linear relationship between the penetration of chloride and the strength of concrete.

\section{Acknowledgments}

The authors thank the Fundação de Amparo à Pesquisa do Estado de São Paulo-FAPESP — for the financial support to develop this investigation.

\section{References}

Aldea, C. M., Young, F., Wang, K., and Shah, S. P. (2000). "Effects of curing conditions on properties of concrete using slag replacement." Cem. Concr. Res., 30(3), 465-472.

Andrade, C. (1993). "Calculation of chloride diffusion coefficients in concrete from ionic migration measurements." Cem. Concr. Res., 23(3), 724-742.

Andrade, C., Castellote, M., Alonso, C., and González, C. (1999). "Relation between colourimetric chloride penetration depth and charge passed in migration tests of the type of Standard ASTM C 1202-91." Cem. Concr. Res., 29(3), 417-421.

Associação Brasilieira de Normas Tecnicas. (1991). "Cimento Portland de alta resistência inicial." ABNT NBR 5733-91, Rio de Janeiro, Brazil.

ASTM. (2005). "Standard test method for electrical indication of concrete's ability to resist chloride ion penetration." C1202-05, West Conshohocken, PA.

Chindaprasirt, P., Chotithanorm, C., Cao, H. T., and Sirivivatnanon, V. (2007). "Influence of fly ash fineness on the chloride penetration of concrete." Constr. Build. Mater., 21(2), 356-361.

Comité Euro-International du Béton. (1989). "Diagnosis and assessment of concrete structures: State-of-the-art report.” Bulletin 192, CEB, Lausanne, Switzerland.

Cyr, M., Lawrence, P., and Ringot, E. (2005). "Mineral admixtures in mortars. Quantification of the physical effects of inert materials on short-term hydration." Cem. Concr. Res., 35(4), 719-730.

Geiker, M., Grube, H., Luping, T., Nilsson, L., and Andrade, C. (1995). "Laboratory test methods." Performance criteria for concrete durability_RILEM Rep. 12, J. Kropp and H. K. Hilsdorf, eds., E\&FN Spon, London, 213-257.

Hanehara, S., Tomosawa, F., Kobayakawa, M., and Hwang, K. (2001). "Effects of water/powder ratio, mixing ratio of fly ash, and curing temperature on pozzolanic reaction of fly ash in cement paste." Cem. Concr. Res., 31(1), 31-39.

Kobayawa, M., Hanehara, S., Hwang, K., and Tomosawa, F. (2003). "Pozzolanic reaction of fly ash cement system." Proc., 11th Int. Congress on the Chemistry of Cement (ICCC), 736-746.

Konin, A., François, R., and Arliguie, G. (1998). "Penetration of chlorides in relation to the microcracking state into reinforced ordinary and high strength concrete." Mater. Struct., 31(5), 310-316.
Li, W., and Roy, D. M. (1986). "Investigation of relations between porosity, pore structure and C1-diffusion of fly ash and blended cement paste." Cem. Conc. Res., 16, 749-759.

Loser, R., Lothenbach, B., Leemann, A., and Tuchschmid, M. (2010). "Chloride resistance of concrete and its binding capacity-Comparison between experimental results and thermodynamic modeling." Cem. Concr. Comp., 32(1), 34-42.

Luping, T., and Nilsson, L. (1992). "Rapid determination of the chloride diffusivity in concrete by applying an electrical field." ACI Mater. J., 89(1), 49-53.

Massazza, F. (1998). "Pozzolana and pozzolanic cements." Lea's chemistry of cement and concrete, P. C. Hewlett, ed., Elsevier, London, 471-631.

Medeiros, M., and Helene, P. (2009). "Surface treatment of reinforced concrete in marine environment: Influence on chloride diffusion coefficient and capillary water absorption." Constr. Build. Mater., 23, 1476-1484.

Medeiros, M. H. F., Hoppe Filho, J., and Helene, P. (2009). "Influence of the slice position on chloride migration tests for concrete in marine conditions." Marine Struct., 22, 128-141.

Mokhtar, K., Loche, J. M., Friedmann, H., Amiri, O., and Ammar, A. (2007). "Steel corrosion in reinforced concrete." Proc., Marine Environment Damage to Atlantic Coast Historical and Transport Works or Structures: Methods of Diagnosis, Repair and of Maintenance, La Rochelle, 1-51.

Montemor, M. F., Simões, A. M. P., and Ferreira, M. G. S. (2003). "Chloride-induced corrosion on reinforcing steel: From the fundamentals to the monitoring techniques." Cem. Concr. Comp., 25(4-5), 491-502.

Poon, C. S., Lam, L., and Wong, Y. L. (2000). "A study on high strength concrete prepared with large volumes of low calcium fly ash." Cem. Concr. Res., 30(3), 447-455.

Ramezanianpour, A. A., and Malhotra, V. M. (1995). "Effect of curing on the compressive strength, resistance to chloride-ion penetration and porosity of concretes incorporating slag, fly ash or silica fume." Cem. Concr. Comp., 17(2), 125-133.

Shi, C. (2004). "Effect of mixing proportions of concrete on its electrical conductivity and the rapid chloride permeability test (ASTM C 1202 or ASSHTO T 277) results." Cem. Concr. Res., 34(3), 537-545.

Snyder, K. A., Feng, X., Keen, B. D., and Mason, T. O. (2003). "Estimating the electric conductivity of cement past pore solution from $\mathrm{OH}^{-}, \mathrm{K}^{+}$ and $\mathrm{NA}^{+}$concentrations." Cem. Concr. Res., 33(6), 793-798.

Sujjavanich, S., Sida, V., and Suwanvitaya, P. (2005). "Chloride permeability and corrosion risk of high-volume fly ash concrete with mid-range water reducer." ACI Mater. J., 102(3), 177-182.

Thomas, M. (1996). "Chloride thresholds in marine concrete." Cem. Concr. Res., 26(4), 513-519.

Wee, T. H., Suryavanshi, A. K., and Tin, S. S. (2000). "Evaluation of rapid chloride permeability test (RCPT) results for concrete containing mineral admixtures." ACI Mater. J., 92(2), 221-231.

Zhang, Y. M., Sun, W., and Yan, H. D. (2000). "Hydration of high-volume fly ash cement pastes." Cem. Concr. Comp., 22(6), 445-452. 